\begin{tabular}{c} 
Volume and Issues Obtainable at Center for Sustainability Research and Consultancy \\
Journal of Accounting and Finance in Emerging Economies \\
ISSN: 2519-0318 ISSN (E) 2518-8488 \\
Volume 5: Issue 2 December 2019 \\
CSRᄃ \\
Journal homepage: www.publishing.globalcsrc.org/jafee \\
\hline
\end{tabular}

\title{
Disclosure of Corporate Social Responsibility Practices
}

\author{
${ }^{1}$ Appel Mahmud, ${ }^{2}$ Donghong Ding, ${ }^{3}$ Md Morshadul Hasan, \\ ${ }^{1}$ University of Science and Technology of China Hefei, Anhui CHINA: mahmud@mail.ustc.edu.cn \\ ${ }^{2}$ School of Management, University of Science and Technology of China: ddh188@gmail.com \\ ${ }^{3}$ Nanjing Audit University, China: arif.morshad@gmail.com
}

\begin{tabular}{|c|c|}
\hline ARTICLE DETAILS & ABSTRACT \\
\hline $\begin{array}{l}\text { History } \\
\text { Revised format: November } 2019 \\
\text { Available Online: December } 2019\end{array}$ & $\begin{array}{l}\text { This study aimed to depict the disclosure of corporate social responsibility } \\
\text { (CSR) practices of commercial banks in Bangladesh. The sample included } \\
\text { annual reports for the year } 2018 \text { of twenty-eight commercial banks out of } \\
\text { thirty commercial banks listed on the Dhaka Stock Exchange (DSE) as of }\end{array}$ \\
\hline $\begin{array}{l}\text { Keywords } \\
\text { CSR, CSR Practice, CSR } \\
\text { Contribution, CSR Disclosure, } \\
\text { Commercial Banks }\end{array}$ & $\begin{array}{l}\text { June } 30,2019 \text {. The data were analyzed using the content analysis } \\
\text { technique. The findings indicate that commercial banks have made CSR } \\
\text { contributions to eight sectors and disclosed CSR information through } \\
\text { thirteen sections of the annual report covering a mixture of four tools. } \\
\text { Moreover, although most of the commercial banks have disclosed some }\end{array}$ \\
\hline $\begin{array}{l}\text { JEL Classification: } \\
M 14, G 21, G 29\end{array}$ & $\begin{array}{l}\text { quantitative data, the aggregate amount of qualitative and mixed types of } \\
\text { CSR disclosure is higher than that of purely quantitative ones. } \\
\text { Additionally, all commercial banks have utilized 'other expense' section } \\
\text { for CSR expenditures in the body of 'financial statements', but most of the } \\
\text { commercial banks have ignored 'corporate social responsibility' sub-head } \\
\text { and preferred 'Donation' or 'Subscription and Donation' sub-heads in the } \\
\text { 'notes to financial statements'. The overall finding indicates that the CSR } \\
\text { disclosure issue in Bangladesh has not received sufficient attention from } \\
\text { the commercial banks. This study, therefore, recommends that CSR } \\
\text { reporting should be formalized and regulated to enhance stakeholders' } \\
\text { confidence in an entity's CSR practice. }\end{array}$ \\
\hline
\end{tabular}

(C) 2019 The authors, under a Creative Commons Attribution-Non

Commercial 4.0

Corresponding author's email address: mahmud@mail.ustc.edu.cn

Recommended citation: Mahmud, A., Ding, D. \& Hasan, M. M., (2019). Disclosure of Corporate Social Responsibility Practices. Journal of Accounting and Finance in Emerging Economies, 5 (2), 295-312

DOI: $10.26710 /$ jafee.v5i2.868

\section{Introduction}

In competitive global markets, the stockholders, as well as, other stakeholders are taking their investment decisions by evaluating both financial and non-financial performances. Carrying out corporate social responsibility (CSR) is one of the most common non-financial performances of a company (Vartiak 2016). Thus, there created a necessity for information about CSR performance along with the financial indicators of a company. In this sense, as a vital route of communicating the social and environmental impacts on society and stakeholders caused by the business operations CSR reporting is becoming critical for a company (Vartiak 2016). According to Reynolds and Yuthas (2008), CSR reporting is an integral part of a corporation's overall set of CSR activities, and CSR disclosure has been emerging over the past years (O’Dwyer, Unerman, and Bradley 2005; Gray, Owen and Maunders 1988). In other words, CSR 
reporting is not only influenced by dominant stakeholders, but also by a combination of the prevalent institutions, values, culture, and history of a particular country (Momin and Parker, 2013). The terminology deploys for such reporting, and disclosure practice is varied worldwide and termed as corporate social disclosure, social accounting, socially responsible accounting, sustainable reporting, and social and ethical accounting (Islam 2012). Additionally, although some companies publish separate CSR reports, most of the companies likely prefer to disclose CSR information through their annual reports because the annual report is a vital document to build the social image of an organization (Luethge and Han 2012;Deegan, Rankin, and Tobin 2002; Gray, Kouhy, and Lavers 1995b; Gray, Kouhy, and Lavers 1995a). In this aspect, a large number of empirical studies investigated the companies' CSR disclosures in the annual report. According to Belal (2001) most of these studies were in the context of developed countries from America, Europe, and Australia (e.g., Fernández-Gago, Cabeza-García, and Nieto 2018; Burritt and Schaltegger 2010; Othman and Ameer 2009; Gray 2006; Adams C., Hill W., and Roberts C. 1998; Kong 1996; Gray et al. 1995a; Roberts 1991; Zeghal and Ahmed 1990). Few types of research explored CSR disclosure practices of companies in developing countries like Bangladesh, India, Malaysia, Singapore, and Thailand (e.g., Mohammad and Kamal 2016; Momin and Parker 2013; Sobhani, Amran, and Zainuddin 2012; Belal and Cooper 2011; Belal and Roberts 2010; Wise and Ali 2009; Murthy 2008; Belal and Owen 2007; Hamid 2004; Kuasirikun and Sherer 2004; Belal 2001; Belal 2000; Imam 2000; Tsang 1998). Evidence from the previous studies indicates that the extent of CSR disclosures in annual report of companies in developing countries is lower than that in the developed countries and in case of Bangladesh, the level of CSR reporting is small and inadequate (Belal and Cooper 2011; Belal 2001; Imam 2000). Only a few of these studies have explored the CSR activities and disclosure sections, contents, and nature. In addition to these, no particular research has addressed the usage of the account head and sub-head for CSR expenditure in the body of the 'financial statements' and the 'notes to financial statements'in the annual report of a company respectively. The present study, therefore, is an attempt to fulfill the above gaps in the CSR literature, especially for Bangladesh.

For several reasons, as are described below, the current researchers have selected Bangladesh and CSR disclosure practices of commercial banks as a study area. Firstly, having grown and fostered in the developed world, CSR issues are also getting its popularity as a research area in developing countries like Bangladesh (Quazi, Rahman, and Keating 2007). Secondly, for her recent remarkable progress from an economic perspective, Bangladesh holds the typical characteristics of a developing country, and like Hossain and Alam (2016) and Haque and Azmat (2015) many authors are recognizing Bangladesh as "a role-model of developing the world" and "an emerging economy in South East Asia". Thirdly, although Bangladesh has already shifted its position "from a low-income country to a middle-income country", it is still facing several social problems (Hossain and Alam 2016). Thus, as development co-partners with the government of Bangladesh, corporations are giving exceptional attention on philanthropy-driven CSR activities to mitigate the social issues and implementing CSR policy to form social equity within their relevant stakeholders such as employees, suppliers, and society-at-large (Karim and Kasim 2018). Fourth, national and multinational corporations in Bangladesh are facing massive pressures to consider the social consequences of their activities and the stakeholders are gradually becoming more attentive to the CSR activities and its disclosures (Belal 2001). Fifth, although CSR concepts have become a focal point among business, academia, and civil society in Bangladesh (Rahim 2013), there is no particular regulatory law in this country exclusively addressed CSR practices. However, since 2008, Bangladesh Bank (BB)-the central bank of Bangladesh, has been monitoring CSR adoption and practices of commercial banks by issuing various circulars and guidelines from time to time (Ullah 2013; Mahbuba and Farzana 2013). Most of the commercial banks, as per the instructions of BB, are providing donations in the areas of patronizing education, poverty lessening programs, sponsoring in sports and social functions, undertaking low-cost housing projects, creating job opportunities for unemployed youth and addressing other community issues (Sobhani et al. 2012). Finally, as the most important and flourishing industry in Bangladesh, banking companies have accomplished global attention in the last few years, and they are 
continuing their enormous contribution to the economic success of the country (Sobhani et al. 2012; Sarker 2000).

\section{Literature Review}

Global pressure and competition as well as the demand for a scandal-free ethical business community are revolutionizing ideal business practices. Institutional reinforcement such as "the Sarbanes Oxley Act" and other regulations are providing an impetus for increased reporting voluntarily. In this sense, government officials, business leaders, and academics are focusing with the intensive attention to the concept of "corporate social responsibility" which denotes the sacrificing profits for the social interest (Reinhardt, Stavins, and Vietor 2008). Previously, firms acted merely as a valuable tool to its shareholders, remained obedient to the laws of the land, and felt no need to become socially responsible (Friedman 2007). But, Carroll (1979) observed that firms have ethical and philanthropic responsibilities apart from those financial and legal obligations. Since then, firms, willing to create a socially responsible image for itself, are expected to operate their economic activities that can hold the environmental sustainability concept while recognizing the interests of its numerous stakeholder groups (Carroll 1999). Reputed firms worldwide, especially in the developed economies, have already moved from the classical 'profit maximizing' approach to a 'socially responsible' approach. They are not only responsible to its stockholders but also its consumers, employees, suppliers, community, and society at large (Rahman 2015). Moreover, companies are now far more concerned about CSR activities and the disclosures thereof to the general public. The scope of disclosure by firms has expanded to satisfy the needs not only of their share or debenture holders but also of other stakeholders, including customers, suppliers, and the government, as well as the general public (Kiliç, Kuzey, and Uyar 2015). The aim is to satisfy the stakeholders while remaining competitive because evidence proves that a company can secure its existing market share and enhance its competitiveness by spending in CSR activities (Jones 1996). Previously, few companies made some voluntary disclosures about social and ethical issues about their economic activities. But now stakeholders have become much aware of their rights, and as a result, they observe firms' CSR activities and disclosures thereof. Thus, companies are now much conscious about their CSR disclosures and whatever they do for the society they want to disclose these in their annual report. In this aspect, Zeghal and Ahmed (1990) examined that the disclosure of social responsibility information of Canadian companies operating in the banking and petroleum industries. Their study indicates that companies provide more qualitative but less quantitative information about their CSR activities. Furthermore, Murthy (2008) utilized the content analysis technique to examine the CSR disclosure practices of the top 16 (sixteen) software companies in India. The study indicates that most of the companies disclose qualitative information and preferred 'other sections' of the annual reports for presenting such disclosure and few companies insert separate sections in their annual reports to disclose CSR information. Also, Tsang (1998) conducted a longitudinal study covering the period from 1986 to 1995 on thirty-three listed public companies of Singapore operating in the banking, food and beverages, and hotel industries. The result shows that most of the companies disclose CSR information relating to human resources and community involvement, and although various companies have increased the amount of CSR expenditure over the period, the extent of disclosure is not in large scale. Sobhani, Amran, and Zainuddin (2009) surveyed 100 listed companies in Bangladesh and they concluded that the level and the extent of CSR disclosures are poor. In the same lineup of studies some researchers examined that most of the companies likely prefer descriptive disclosures and focusing on 'good' CSR-related information in their annual reports, but the extent of such disclosure is still inadequate (Sufian 2012; Belal 2001; Imam 2000).

Furthermore, Porag (2014) stated that most of the companies practice CSR in their way, and a few companies have separate CSR department. However, Bangladesh has a good number of rules and regulations, e.g. the Environmental Protection Act, 1995; the Companies Act, 1994; the Banking Companies Act, 1991; the Industrial Relations Ordinance, 1969; the Factories Act, 1965; the Employment of Labor (Standing Orders) Act, 1965; the Payment of Wages Act, 1936; and the Workmen Compensation Act, 1923 (Belal and Roberts 2010). But, Khatun (2014) mentioned that the major Bangladeshi laws 
related to corporate regulation and responsibility do not have the necessary features to develop a CSRcentered corporate culture in the country. Moreover, although from July 1, 2010, the government has initiated CSR reporting by the banking companies to Bangladesh Bank, still there is a demand for a cleaner environment and social accountability of banking companies.

Due to the heightened interest in the concept of CSR and its reporting and what it entails, particularly in developed countries, many researchers have conducted studies in this field. But the developing countries are far behind in responding to the increased concern about the issue of CSR reporting. Previously, some researchers explored the volume of CSR disclosures in terms of pages devoted to social reporting and concluded that CSR information is descriptive and the quantity of exposure is also inadequate and weak (Belal 2000; Belal 2001; Imam 2000). Furthermore, Hackston and Milne (1996) investigated the pictorial presentation of CSR activities, and Vourvachis et al. (2016) examined the extent and the volume of CSR disclosures in terms of pages, pictures, and graphs inserted in the annual report by a company. Additionally, some authors noticed the nature of disclosure whether it is purely qualitative, purely quantitative or mixed of both (Belal 2001; Williams and Ho Wern Pei 1999; Walden and Schwartz 1997; Zeghal and Ahmed 1990).

Moreover, the above examinations were limited to the number of companies having CSR disclosures with particular purposes. They did not explored CSR disclosures in terms of the CSR activities and its disclosure sections, contents, and nature of information as well as usages of the account head and subhead for CSR expenditure at the body of 'financial statements' and 'notes to financial statements' in the annual report of a company as a whole. Accordingly, the present study adds to the growing body of literature in the area by focusing on previous issues.

\section{Method}

\subsection{Data Source}

Previously, some researchers investigated the annual reports to explore the extent and the volume of CSR disclosures (Luethge and Han 2012; Deegan et al. 2002; Gray et al. 1995a; Gray et al. 1995; Gray et al. 1988). The earlier researchers marked that the annual report as a vital document of an organization can construct the social image of a particular entity. Thus, CSR performance data is becoming an increasingly important feature of companies' annual reports (Vartiak 2016). However, in Bangladesh, corporations communicate their primary means of information through the annual report (Hossain, Islam, and Andrew 2006; Belal 2001). Previously many researchers considered the annual report as a secondary source of data for their studies purpose (e.g., Momin and Parker 2013; Sobhani et al. 2012; Belal 2008; Belal 2001). Thus, to conduct this study, we have investigated the annual report 2018 of twenty-eight out of the thirty commercial banks listed on the Dhaka Stock Exchange (DSE) as of June 30, 2019.

\subsection{Data Analysis and Presentation}

According to Krippendorf (2004), content analysis is one of the standard methodologies in the social sciences for studying the content of the communication. It also refers to a suitable technique for making inferences by objectively and systematically identifying specified characteristics of information. Additionally, content analysis is a well-known technique to quantify the voluntarily disclosed corporate social details (Puncheva-Michelotti, Hudson, and Jin 2018). Previously, many studies, around the world, investigated the content analysis of companies' annual reports to measure the volume of CSR disclosures (Vourvachis, Woodward, Woodward, and Patten 2016). Additionally, some authors conducted studies based on content analysis of companies' annual reports to explore the corporate social reporting practices in Bangladesh (Sobhani et al. 2012; Sobhani et al. 2009; Belal 2008; Belal 2001).

Thus, to explore the CSR issue, several times the responsible members of the research team have read the printed version of the annual reports of the sampled commercial banks from the first page to the last one. The researchers have categorized the CSR activities into eight groups and recognized as the CSR section 
if there is any CSR information throughout the different parts of the annual report. They have also measured the volume of disclosure in term of the number of the sentence, picture, table, graph and page contained CSR information; and determined the nature of data (qualitative, quantitative and mixture) based on whether it is descriptive in nature or figure expressed with taka (Bangladeshi Currency). Furthermore, the study has examined the body of 'financial statements' and 'notes to financial statements' to get the specific account head and sub-head that contains the amount of CSR expenditure for a particular financial year.

Moreover, to look closely at the nature of the entire aggregate disclosures made by the sampled banks $\left(\sum \mathrm{DN}\right)$ across the vital sections, whether it is (i) purely qualitative or (ii) purely quantitative or (iii) both (qualitative and quantitative) in a particular section ( $\mathrm{SN}$ ), and the entire disclosures made by banks in a particular section, DN, should be the summation of all three types of disclosure. For this purpose, researchers of this study have constructed the following formulae

$\mathrm{DN}=\mathrm{QLN}+\mathrm{QAN}+\mathrm{QLAN}$

$\sum \mathrm{DN}=\sum \mathrm{QLN}+\sum \mathrm{QAN}+\sum \mathrm{QLAN}$

Where

DN denotes the total number of disclosures by all banks in a single section

QLN denotes the total number of purely qualitative disclosures by all banks in a single section

QAN denotes the total number of purely quantitative disclosures by all banks in one section

QLAN denotes the total number of mixed disclosures by all banks in a single section

However, utilizing the content analysis technique, thisqualitative study has presented its outcome through various tables with a brief description of each of them.

\section{Findings}

\subsection{CSR Activities of Sampled Banks}

To assist in the understanding of accurately which types of CSR activities are performed by the commercial banks, an analysis has been done. In 2018 almost every commercial bank has contributed to the educational development of Bangladesh through scholarship programs, stipend package, and granting research funds. Furthermore, all of them have granted donations to hospitals, clinics, arranging free treatment for insolvent patients, etc. Almost every commercial bank has also donated to flood-affected, and cold waves affected people. Moreover, most of them have played very sincere roles in protecting the environment, but some have not mentioned anything in this aspect. Some banks have contributed to sectors other than those included in previous sections, for example, patronization of sports, and cultural functions. A few numbers of banks have allotted CSR funds to construct buildings for schools, colleges, and universities, and an extension of the road. Very few banks have disclosed their human-resourcerelated packages in their CSR sections. However, we have found out eight particular CSR sectors in which commercial banks in Bangladesh likely prefer to make CSR contributions and hence they have disclosed information related to these CSR activities in their annual reports. In general, the main CSR sectors can be categorized into relating to eight major areas as follows:

\section{Table 1: Common sectors of CSR of commercial banks in Bangladesh}

Table 1 indicates that there are eight specific sectors of CSR, i.e., contribution to education, health, humanitarian \& disaster management, environment, cultural welfare, infrastructural development, income-generating activities, and others. As per their statements, the motto of this CSR is to help the underprivileged people and environmental sustainability for sustainable development of the country.

\begin{tabular}{|l|ll|l|}
\hline Sl. No. & The sector of & Specific Activities \\
\hline
\end{tabular} 


\begin{tabular}{|c|c|}
\hline CSR of Banks & \\
\hline Education & $\begin{array}{l}\text { Providing scholarship to insolvent but meritorious students } \\
\text { Donating for purchasing study materials such as laptop computer, school } \\
\text { bag, exercise books, and so on } \\
\text { Providing research fund in tertiary level education }\end{array}$ \\
\hline Health & $\begin{array}{l}\text { Arranging free medical camp for treatment of distressed community of the } \\
\text { country } \\
\text { Donating to purchase medical equipment, ambulance, food and medicine to } \\
\text { help the needy patients } \\
\text { Organizing blood donation camp and supporting acid burn victims }\end{array}$ \\
\hline $\begin{array}{l}\text { Humanitarian } \\
\text { and disaster } \\
\text { relief }\end{array}$ & $\begin{array}{l}\text { Donating to prime minister's relief fund } \\
\text { Distributing relief materials to flood-affected and giving warm cloth to the } \\
\text { less advantaged people survive the winter } \\
\text { Granting fund to the martyrs of various tragic events such as (BDR Mutiny } \\
\text { and Rana Plaza Collapse Tragedy) }\end{array}$ \\
\hline Environment & $\begin{array}{l}\text { Arranging tree plantation programs and organizing various young climate } \\
\text { change competition } \\
\text { Adoption of energy efficient, carbon footprint reducing internal processes } \\
\text { and practices in own offices and establishments are in progress } \\
\text { Developing green school project and city beautification program }\end{array}$ \\
\hline Cultural welfare & $\begin{array}{l}\text { Arranging award giving ceremony to promote Bangla music, literature and } \\
\text { sports } \\
\text { Sponsoring in sports and cultural events } \\
\text { Organizing a book fair program for underprivileged children at the national } \\
\text { book fair in Bangla Academy premises. }\end{array}$ \\
\hline $\begin{array}{l}\text { Infrastructural } \\
\text { development }\end{array}$ & $\begin{array}{l}\text { Donating to construct school \& library building, hospital building, and } \\
\text { foundations } \\
\text { Building senior citizens care centre and daycare centre for children } \\
\text { Building extension road }\end{array}$ \\
\hline $\begin{array}{l}\text { Income } \\
\text { generating } \\
\text { activities }\end{array}$ & $\begin{array}{l}\text { Arranging various training sessions to develop the skill of farmer, RMG } \\
\text { workers, and other technical sectors' labors } \\
\text { Arranging awarding giving ceremony to recognize and honor leadership, } \\
\text { entrepreneurial talent, and best practices of individual micro-entrepreneurs in } \\
\text { Bangladesh. } \\
\text { Promoting youth leadership and women empowerment through arranging } \\
\text { women's debate competition in the country }\end{array}$ \\
\hline Others & $\begin{array}{l}\text { Presenting activities that are aimed at the benefit of society in general, } \\
\text { including assistance to charitable and non-profit organizations involving } \\
\text { donations to distressed, sponsorships in various activities, steps taken to } \\
\text { alleviate poverty, etc. }\end{array}$ \\
\hline
\end{tabular}

Source: Researchers' compilation from the annual reports of sampled banks

Table 2: Common CSR activity disclosed in the annual report

Table 2 is an elaboration of these CSR activities related disclosures by the banks in their annual reports. The calculated percentage (\%) indicates the ratio of the banks which have addressed the particular CSR activity and its disclosure in annual reports.

\begin{tabular}{|l|l|l|l|}
\hline Sl. No. & CSR activities of banks & No. of Banks (out of 28) & Percentage (\%) \\
\hline 1 & Education & 28 & 100 \\
\hline 2 & Health & 28 & 100 \\
\hline 3 & Humanitarian and disaster relief & 28 & 100 \\
\hline
\end{tabular}




\begin{tabular}{|l|l|l|l|}
\hline 4 & Environment & 22 & 78.57 \\
\hline 5 & Cultural welfare & 15 & 53.57 \\
\hline 6 & Infrastructural development & 9 & 32.14 \\
\hline 7 & Income generating activities & 7 & 25 \\
\hline 8 & Others & 12 & 57.14 \\
\hline
\end{tabular}

Source: Researchers' compilation from the annual reports of sampled banks

Table 2 indicates that in 2018, all sampled banks (100\%) have disclosed information about their CSR contribution to education, health, and humanitarian and disaster relief. In addition to this, approximately $78.57 \%$ of sampled banks have disclosed their steps taken to protect the environment, and $53.57 \%$ of sampled banks have published their contributions toward building a culture based progressive society. But less than half of the total sampled bank has disclosed information about their CSR contribution to infrastructural development and income-generating activities. Moreover, the majority of banks have published their initiatives to address other social issues.

\subsection{Sections of CSR Disclosures in the Annual Reports}

The study indicates that all sampled banks have made CSR disclosure in the annual report 2018. But they have used a variety of sections of annual reports for such disclosure because there is no standard format for CSR disclosures in Bangladesh.

Table 3: CSR Disclosure Sections in the Annual Reports

Table 3 indicates that the sampled banks have used the thirteen sections in annual reports to disclose CSR information. These sections can be called relevant CSR disclosure sections of banks in Bangladesh.

\begin{tabular}{|l|l|l|l|}
\hline $\begin{array}{l}\text { Section } \\
\text { Code } \\
\text { (SN) }\end{array}$ & $\begin{array}{l}\text { CSR } \\
\text { Disclosure Sections }\end{array}$ & $\begin{array}{l}\text { Total No. of Banks making } \\
\text { Disclosure (DN), N=28 }\end{array}$ & $\begin{array}{l}\text { Percentage } \\
(\%)\end{array}$ \\
\hline S1 & Vision & 4 & 14.29 \\
\hline S2 & Mission & 5 & 17.86 \\
\hline S3 & Strategic Objective & 5 & 17.86 \\
\hline S4 & Core Value & 5 & 17.86 \\
\hline S5 & Bank's Profile & 2 & 7.14 \\
\hline S6 & Message from Chairman & 14 & 50.00 \\
\hline S7 & Message from President/CEO/MD & 17 & 60.71 \\
\hline S8 & Directors' Report & 23 & 82.14 \\
\hline S9 & Separate CSR Section & 20 & 71.43 \\
\hline S10 & Sustainability Reporting & 14 & 50.00 \\
\hline S11 & Green Banking & 16 & 57.14 \\
\hline S12 & Other Sections & 5 & 17.86 \\
\hline S13 & Notes to Financial Statements & 24 & 85.71 \\
\hline $\begin{array}{l}\text { Aggregate } \text { total disclosures made by sampled } \\
\text { banks }\left(\sum D N\right)\end{array}$ & 154 & \\
\hline
\end{tabular}

Source: Researchers' compilation from the annual reports of sampled banks

Table 3 indicates that the sampled banks have used the above thirteen sections in annual reports to disclose CSR information. These sections can be called relevant CSR disclosure sections of banks in Bangladesh. If all twenty-eight banks have used all thirteen critical parts of their annual reports for CSR disclosure, there would have been $364(28 \times 13)$ disclosures theoretically. But in reality, the sampled banks have made a combined total of only 154 disclosures across these sections revealing the fact that CSR disclosure has not received sufficient attention from the banking industry of Bangladesh. However, the 
most popular parts are S13, and S8 (used by $85.71 \%$ and $82.14 \%$ banks respectively) and the least favorite section is S5 (used by only $7.14 \%$ banks). Furthermore, most of the sampled banks $(71.43 \%)$ have dedicated a separate section for CSR disclosure in their annual reports. The overall finding also indicates that most of the sampled banks generally use more than one part to disclose CSR information.

Table 4: Frequency distribution for usage of CSR disclosure sections

Table 4 indicates the range of usage of sections by a particular bank. The possible outcome is a maximum of thirteen sections and minimum one section.

\begin{tabular}{|l|l|l|}
\hline Section(s) used & No. of Bank(s) & Percentage (\%) of Sampled Banks \\
\hline 1 Section only & 2 & 7.14 \\
\hline 2 Sections & 3 & 10.71 \\
\hline 3 Sections & 3 & 10.71 \\
\hline 4 Sections & 4 & 14.29 \\
\hline 5 Sections & 7 & 25.00 \\
\hline 6 Sections & 2 & 7.14 \\
\hline 7 Sections & 6 & 21.43 \\
\hline Eight Sections & 1 & 3.57 \\
\hline
\end{tabular}

Source: Researchers' compilation from the annual reports of sampled banks

Table 4 indicates that no bank has used all thirteen relevant sections for CSR disclosure in the annual report 2018. Only a particular bank has used a maximum of eight parts, and approximately $92.86 \%$ of banks have used two or more sections, whereas about $7.14 \%$ have used only one division.

\section{a. The measurement of contents of CSR disclosures}

The sampled banks generally use four tools such as descriptive, photo, table, and graph to disclose CSR information. The study has also attempted to measure the contents of CSR disclosures in the annual reports in terms of the number of sentences, photos, tables and graphs placed and in addition to these; it has also determined the volume of pages that contains CSR information.

\section{Table 5: Use of tools (Descriptive, Photo, Table and Graph) for CSR disclosure}

Table 5 carries the tools of CSR disclosure and how many banks have utilized each of them to disclose CSR information.

\begin{tabular}{|l|l|l|l|l|}
\hline Tools used & No. of Banks & Percentage (\%) & Highest Value & Lowest Value \\
\hline Sentence & 28 & 100.00 & 1628 & 4 \\
\hline Picture & 26 & 92.86 & 70 & 1 \\
\hline Table & 14 & 50.00 & 28 & 1 \\
\hline Graph & 9 & 32.14 & 38 & 1 \\
\hline
\end{tabular}

Source: Researchers' compilation from the annual reports of sampled banks

Table 5 indicates that all commercial banks have presented CSR information in descriptive form using sentences ranging from as high as 1628 to as low as 4 . Moreover, approximately $92.86 \%$ of sampled banks have attached pictures (ranging from as high as 70 to as little as 1), and precisely $50 \%$ of sampled banks have inserted tables (ranging from as high as 28 to as low as 1) for CSR disclosure. On the contrary, only $32.14 \%$ of sampled banks have to prefer to use the graph for their CSR disclosure.

The number of tools has been used by the banks also varied, which are shown in the following table. 
Table 6: Frequency distribution of the number of tools used

Table 6 indicates that a bank can utilize maximum four tools and minimum 1 and the multiple combinations with the usages of descriptive, picture, table, and graph tools.

\begin{tabular}{|l|l|l|}
\hline Frequency & No. of Banks & Percentage (\%) \\
\hline Used one tool only & 2 & 7.14 \\
\hline Used two tools & 11 & 39.29 \\
\hline Used three tools & 7 & 25.00 \\
\hline Used four tools & 8 & 28.57 \\
\hline
\end{tabular}

Source: Researchers' compilation from the annual reports of sampled banks

Table 6 indicates that approximately $39.29 \%$ of the sampled banks have used two tools, approximately $28.57 \%$ of sampled banks have used four tools, and only $25 \%$ of banks have used three tools for CSR disclosure. Moreover, not all sampled banks have used all tools.

In the next sub-section, this study has also measured the contents of CSR disclosures in terms of the number of sentences written by the banks to discuss their CSR issue. Researchers have categorized the observations into five closed intervals and one open interval.

Table 7: Number of sentences written for CSR disclosures

Table 7 indicates the volume of detailed explanation in term of the number of sentences used for CSR disclosure in the annual report. The range is 1 to more than 200 sentences.

\begin{tabular}{|l|l|l|}
\hline Intervals & No. of Bank(s) & Percentage (\%) \\
\hline 0 sentence & 0 & 0.00 \\
\hline $1-50$ sentence(s) & 10 & 35.71 \\
\hline $51-100$ sentences & 11 & 39.29 \\
\hline $101-150$ sentences & 1 & 3.57 \\
\hline $150-200$ sentences & 3 & 10.71 \\
\hline More than 200 sentences & 3 & 10.71 \\
\hline
\end{tabular}

Source: Researchers' compilation from the annual reports of sampled banks

Table 7 indicates that approximately $39.29 \%$ of sampled banks have written 51-100 sentences, followed by $35.71 \%$ of the sampled banks have written below 51 sentences. The highest and lowest numbers of sentences are 1628 and 4 respectively. Moreover, only three sampled banks have written over 200 sentences for disclosures their CSR issues.

This study has further measured the contents of CSR disclosures in terms of the number of related pictures posted in annual reports. Five closed intervals and one open interval are developed for this purpose.

\section{Table 8: Number of photo posted for CSR disclosures}

Table 8 presents the status of pictorial presentation of CSR activities of banks. The number of photos is varied from bank to bank, and the range is 0 to more than 20 photos.

\begin{tabular}{|l|l|l|}
\hline Intervals & No. of Banks & Percentage (\%) \\
\hline 0 Photo & 2 & 7.14 \\
\hline 1-5 Photo(s) & 9 & 32.14 \\
\hline 6-10 Photos & 7 & 25.00 \\
\hline
\end{tabular}




\begin{tabular}{|l|l|l|}
\hline $11-15$ Photos & 2 & 7.14 \\
\hline $16-20$ Photos & 3 & 10.71 \\
\hline More than 20 Photos & 5 & 17.86 \\
\hline
\end{tabular}

Source: Researchers' compilation from the annual reports of sampled banks

Table 8 indicates that approximately $32.14 \%$ of sampled banks have posted the 1-5 photo(s) followed by $25 \%$ of sampled banks' posting of 6-10 photos and two sampled banks (7.14\%) have not posted any photo related to their CSR activities. Moreover, approximately $17.86 \%$ of banks have attached more than 20 photos.

Additionally, this study has also measured the contents of CSR disclosures in terms of the number of tables and graphs placed in annual reports. Six closed intervals and one open interval are developed for these purposes.

Table 9: Number of tables placed for CSR disclosures

Table 9 contains the CSR disclosure of sampled banks in term of the number of the table used by the banks. The range is 0 to more than five tables inserted by various banks.

\begin{tabular}{|l|l|l|}
\hline Use of Table(s) & No. of Bank(s) & Percentage (\%) \\
\hline 0 table & 14 & 50.00 \\
\hline 1 table & 5 & 17.86 \\
\hline 2 tables & 4 & 14.29 \\
\hline 3 tables & 0 & 0.00 \\
\hline 4 tables & 2 & 7.14 \\
\hline 5 tables & 2 & 7.14 \\
\hline More than 5 tables & 1 & 3.57 \\
\hline
\end{tabular}

Source: Researchers' compilation from the annual reports of sampled banks

Table 9 indicates that half of the sampled banks have not inserted any table, and only $17.85 \%$ of banks have placed five or more tables (out of the remaining 50\%) for CSR disclosures.

Table 10: Number of graphs placed for CSR disclosures

Table 10 shows the number of graphs usually used by the banks to present their CSR issues in the annual report. The range is 0 to more than five graphs that contained CSR related information of banks.

\begin{tabular}{|l|l|l|}
\hline Use of Graph(s) & No. of Bank(s) & Percentage (\%) \\
\hline 0 graph & 19 & 67.86 \\
\hline 1 graph & 3 & 10.71 \\
\hline 2 graphs & 2 & 7.14 \\
\hline 3 graphs & 0 & 0.00 \\
\hline 4 graphs & 1 & 3.57 \\
\hline 5 graphs & 2 & 7.14 \\
\hline More than 5 graphs & 1 & 3.57 \\
\hline
\end{tabular}

Source: Researchers' compilation from the annual reports of sampled banks 
Table 10 indicates that approximately $67.86 \%$ of sampled banks have not inserted any graph and only $10.71 \%$ of sampled banks have placed only three graphs, and the remaining $21.43 \%$ of sampled banks have used two or more graphs for CSR disclosures.

Finally, to measure the extent and the length of contents of CSR disclosures, this study has countedthe number of pages in the annual report and categorized the observations into five closed intervals and one open interval.

Table 11: Number of page(s) used in the annual reports for CSR disclosures

Table 11 measures the utilization of the number of pages to disclose CSR related information of banks. The usages of the page(s) are between 1 to more than 20 pages.

\begin{tabular}{|c|c|c|c|c|}
\hline Intervals & \begin{tabular}{|l|} 
No. of \\
Bank(s) \\
\end{tabular} & Percentage (\%) & $\begin{array}{l}\text { Highest } \\
\text { Value }\end{array}$ & $\begin{array}{l}\text { Lowest } \\
\text { Value }\end{array}$ \\
\hline 0 page only & 0 & 0.00 & \multirow{6}{*}{88} & \multirow{6}{*}{. } \\
\hline $1-5$ page $(\mathrm{s})$ & 15 & 53.57 & & \\
\hline 6-10 pages & 8 & 28.57 & & \\
\hline 11-15 pages & 2 & 7.14 & & \\
\hline 16-20 pages & 1 & 3.57 & & \\
\hline More than 20 pages & 2 & 7.14 & & \\
\hline
\end{tabular}

Source: Researchers' compilation from the annual reports of sampled banks

Table 11 indicates that more than $50 \%$ of sampled banks have confined CSR disclosures within 1-5 page(s). Moreover, approximately $28.57 \%$ of sampled banks have utilized 6-10 pages, and only $7.14 \%$ of banks have applied more than 20 pages to disclose CSR information. The highest number of pages used is 88 , and the lowest is 1 .

\subsection{Nature of CSR Disclosures in the Annual Reports}

This section of the study has examined, broadly, the nature of CSR disclosures in the annual report 2018 of the sampled banks. Firstly, the researchers have questioned whether CSR disclosures made by all banks contained a mixture of qualitative and quantitative information, at least in one crucial section or not.

\section{Table 12: Nature of CSR disclosure practices of sampled banks}

Table 12 shows the nature of disclosure, whether it is mixed with qualitative and quantitative information or not.

\begin{tabular}{|l|l|l|}
\hline $\begin{array}{l}\text { Nature of Disclosure Practice } \\
\text { (Mixture or Non-mixture) }\end{array}$ & No. of Banks & Percentage (\%) \\
\hline $\begin{array}{l}\text { Mixed disclosure occurred at least in } \\
\text { one vital section }\end{array}$ & 26 & 92.86 \\
\hline $\begin{array}{l}\text { No mixed disclosure occurred in } \\
\text { any critical part }\end{array}$ & 2 & 7.14 \\
\hline
\end{tabular}

Source: Researchers' compilation from the annual reports of sampled banks

Table 12 indicates that the mixed disclosure is the industry practice for banking industry's CSR reporting as most of the banks (92.86\%) have used a mixture of qualitative and quantitative information at least in one central CSR disclosure section.

Secondly, researchers have examined whether the relevant CSR disclosure sections used by the banks are purely qualitative or purely quantitative or a mixture of both. 


\section{Table 13: Nature of CSR disclosure sections}

Table 13 presents the section which contains purely qualitative or quantitative or mixed of both. Among 13 original parts five sections contain purely qualitative, only one section contains strictly quantitative, and seven sections include mixed types of CSR information.

\begin{tabular}{|l|l|l|}
\hline Nature of Disclosure & SN & No. of Sections in each Category \\
\hline Purely Qualitative & S1 - S5 & 5 \\
\hline Purely Quantitative & S13 & 1 \\
\hline Mixed & S6-S12 & 7 \\
\hline
\end{tabular}

Source: Researchers' compilation from the annual reports of sampled banks

Table 13 indicates that only one section is purely quantitative out of the thirteen vital parts. The remaining twelve sections contain either purely qualitative disclosures or mixed disclosures.

The findings of Table 3 and Table 13 enable the study to (i) discover which nature of CSR disclosure sections contained how many actual disclosures, (ii) compare those actual disclosures with the theoretically possible number of exposures and (iii) calculate the discrepancies (if any). For this purpose,

Table 14 is constructed, which is given below

Table 14: Comparison between the number of actual and theoretically possible disclosures according to the nature of CSR disclosure sections

\begin{tabular}{|l|l|l|l|l|}
\hline Particular & $\begin{array}{l}\text { Purely } \\
\text { Qualitative }\end{array}$ & $\begin{array}{l}\text { Purely } \\
\text { Quantitative }\end{array}$ & Mixed & Total \\
\hline $\begin{array}{l}\text { No. of CSR Disclosure } \\
\text { Sections }\end{array}$ & 5 & 1 & 7 & 13 \\
\hline $\begin{array}{l}\text { No. of Actual Disclosures } \\
\text { Occurred }\end{array}$ & 21 & 24 & 109 & 154 \\
\hline $\begin{array}{l}\text { No. of Theoretically Possible } \\
\text { Disclosures }\end{array}$ & 140 & 28 & 196 & 364 \\
\hline $\begin{array}{l}\text { Discrepancies } \\
\text { (Actual minus Theoretical) }\end{array}$ & -119 & -4 & -87 & -210 \\
\hline $\begin{array}{l}\text { Actual to-Theoretical } \\
\text { Disclosure Ratio }\end{array}$ & $15 \%$ & $85.71 \%$ & $55.61 \%$ & $42.31 \%$ \\
\hline
\end{tabular}

Source: Researchers' compilation

The previous finding of this study (Table 3) indicates that S13, the solitary purely quantitative disclosure section, is the most popular CSR-disclosure section of the annual report. The actual number of disclosures in this section is 24 compared to the theoretically possible $28(28 \times 1)$. The study has also found that the five purely qualitative disclosure sections $(\mathrm{S} 1-\mathrm{S} 5)$ are among the least favorite CSR disclosure sections of the annual report. The actual number of disclosures in these sections is a total of $21(4+5+5+5+2)$ comparing to the theoretically possible $140(28 \times 5)$ exposures; the number of real revelation is weak. A meager actual-to-theoretical disclosure ratio, in this case, indicates that the sampled banks are lagging in terms of their CSR disclosures in purely qualitative sections. The study has further found that the seven mixed disclosure sections (S6 - S12) are also the most frequently used CSR-disclosure sections after S13. The actual number of disclosures in these sections is a total of $109(14+17+23+20+14+16+5)$ comparing to the theoretically possible $196(28 \times 7)$ exposures; it is moderate. The average actual-to-theoretical disclosure ratio, in this case, indicates that the sampled banks are more comfortable to use S6 - S12 than S1 - S5 for CSR disclosure. Finally, an actual meager number of 154 revelations by the banks compared to the theoretically possible $364(28 \times 13)$ exposures reveal the fact that the CSR disclosure issue is not received sufficient attention by the banking industry of Bangladesh. 
Thirdly, the study has extended its attempt to look closely at the nature of the entire aggregate disclosures made by the banks ( $\left.\sum \mathrm{DN}\right)$ across the critical sections. A bank may choose to disclose (i) purely qualitative or (ii) strictly quantitative or (iii) both (qualitative and quantitative) information in a particular section (SN). Thus, entire disclosures are made by all banks in a specific segment; DN should be the summation of all three types of exposure. The study, therefore, has reconstructed Table 3, which is shown in Table 15.

Table 15: Breakdown of total disclosures in all sections according to the nature of disclosure (Qualitative/Quantitative/Mixed)

\begin{tabular}{|c|c|c|c|c|c|c|c|}
\hline SN & DN & $=$ & QLN & + & QAN & + & QLAN \\
\hline S1 & 4 & $=$ & 4 & + & 0 & + & 0 \\
\hline S2 & 5 & $=$ & 5 & + & 0 & + & 0 \\
\hline S3 & 5 & $=$ & 5 & + & 0 & + & 0 \\
\hline S4 & 5 & $=$ & 5 & + & 0 & + & 0 \\
\hline S5 & 2 & $=$ & 2 & + & 0 & + & 0 \\
\hline S6 & 14 & $=$ & 7 & + & 0 & + & 7 \\
\hline S7 & 17 & $=$ & 11 & + & 0 & + & 6 \\
\hline S8 & 23 & $=$ & 10 & + & 0 & + & 13 \\
\hline S9 & 20 & $=$ & 1 & + & 0 & + & \\
\hline S10 & 14 & $=$ & 4 & + & 0 & + & 10 \\
\hline S11 & 16 & $=$ & 6 & + & 0 & + & 10 \\
\hline S12 & 5 & $=$ & 5 & + & 0 & & 0 \\
\hline S13 & 24 & $=$ & 0 & + & 24 & + & 0 \\
\hline \multirow{2}{*}{$\begin{array}{l}\text { Aggregate total number of disclosures by sampled banks } \\
\text { across sections according to the nature of disclosures }\end{array}$} & $\sum \mathrm{DN}$ & $=$ & $\sum \mathrm{QLN}$ & + & $\sum \mathrm{QAN}$ & + & $\sum$ QLAN \\
\hline & 154 & $=$ & 65 & + & 24 & + & 65 \\
\hline
\end{tabular}

Source: Researchers' compilation

Table 15 indicates that the total number of qualitative disclosures and mixed disclosures made by the banks are precisely equal in 2018. But in the case of seven mixed disclosure sections for CSR (S6 - S12), the scenario is quite different. These seven sections are dominated by mixed disclosures. Out of 109 disclosures in mixed disclosure sections (referring to Table 14), a total of $44(7+11+10+1+4+6+5)$ disclosures are purely qualitative whereas a total of $65(7+6+13+19+10+10)$ disclosures are mixed (both qualitative and quantitative).

\subsection{The Utilization of Head and Sub-Head(s) to Account for CSR Expenditure in 'Financial Statements' and 'Notes to Financial Statements'}

All sampled banks have used 'Other Expenses' account as an account title in the body of the 'Profit and Loss Account' and provided details of 'Other Expenses' under some sub-heads in the 'Notes to the Financial Statements'.

Table 16: The usages of sub-head(s) to account for CSR expenditure in the 'notes to financial statements'

Table 16 shows the different sub-heads which have been used in the 'Other Expenses" explanation section of 'Notes to Financial Statements' to show the CSR expenditure of banks.

\begin{tabular}{|l|l|l|}
\hline Sub-heads & Percentage (\%) & No. of Banks \\
\hline Corporate Social Responsibility & 17.86 & 5 \\
\hline Donation & 42.86 & 12 \\
\hline
\end{tabular}




\begin{tabular}{|l|l|l|}
\hline Sponsorship & 7.14 & 2 \\
\hline Subscription and Donation & 32.14 & 9 \\
\hline Contribution to Foundation & 14.29 & 4 \\
\hline Others & 10.71 & 3 \\
\hline No sub-head & 14.29 & 4 \\
\hline
\end{tabular}

Source: Researchers' compilation from the annual reports of sampled banks

According to Table 16, approximately $42.86 \%$ of sampled banks preferred to 'Donation' followed by approximately $32.14 \%$ of sampled banks usage of 'Subscription and Donation' sub-headto disclose CSR expenses. Moreover, only $17.86 \%$ (approximate) of sampled banks have used 'Corporate Social Responsibility' sub-head clearly in the 'Notes to Financial Statements' to disclose CSR expense. Some of the sampled banks (14.29\%) have established Foundations in their names to perform CSR activities and used 'Contribution to Foundation' sub-head to show their CSR expense. However, approximately $14.29 \%$ of sampled banks have not provided any sub-head to disclose CSR expense. Thus, there is no scope for external users to know the actual CSR expense.

\section{Discussion}

The overall findings of the study indicate that the sampled banks have different CSR disclosure practices. Although there are eight prime sections of CSR contribution, all banks do not contribute to all the sectors and contribution to education, health and humanitarian and disaster relief are common for all. Additionally, large numbers of banks take the initiative to protect environmental, whereas moderate amounts of banks contribute to building a culture based progressive society and a very few numbers of banks think about infrastructure development and income-generating activities and its disclosures.

Moreover, there is no uniformity in the usage of sections in annual reports for CSR disclosures. The study has identified thirteen different parts that contain CSR information, but no bank used all these sections in 2018. Some commercial banks have used only one section while others have used more than one article, and the maximum number of users is confined to eight parts. However, eight commercial banks do not have any 'Separate CSR Section' in their annual reports. The sampled banks have options of four tools such as descriptive (writing), pictures, tables, and graphs to provide CSR information, but they don't focus equally on each instrument. Eight commercial banks have used all four tools, seven banks have used three tools, eleven banks have used two devices, and two banks have used only one tool. Although all banks have used a descriptive tool such as writing several sentences, twenty-six banks have posted the picture(s), fourteen banks have inserted table(s), and only nine banks have placed graph(s) that match to their CSR activities. The usages of pages are also varied, and the range is from1 page to 88 pages.

Furthermore, these publicly traded commercial banks prefer to disclose a mixture of qualitative and quantitative CSR information. Only one section ('Notes to the Financial Statements') contains purely quantitative CSR disclosure, five chapters cover purely qualitative CSR disclosure, and maximum of seven sections reveal a mixture of both. Although actual-to-theoretical disclosure ratio for purely quantitative CSR information as well, a meager actual-to-theoretical disclosure ratio for purely qualitative sections' disclosures and an average actual-to-theoretical disclosure ratio for mixed sections' exposures indicate that the sampled banks are lagging in terms of qualitative and mixed CSR disclosures. However, an actual meager number of 154 revelations by the banks compared to the theoretically possible 364 $(28 \times 13)$ exposures reveal the fact that the CSR disclosure issue is not received sufficient attention by the banking industry of Bangladesh.

Moreover, the sampled banks have utilized 'Other Expenses' account head in the 'Profit and Loss Account' to show CSR expenditures but the sub-heads to reveal details of 'Other Expenses' in the 'Notes to the Financial Statements' are not identical. Most of the sampled banks prefer to 'Donation' or 'Subscription and Donation' sub-head, and only five banks have used 'Corporate Social Responsibility' 
sub-head whereas four banks are failed to show any sub-head for CSR expenditures. Thus, it is very tough for external users to know the exact amount of CSR expenditure from the annual reports.

\section{Theoretical and Practical Implications}

International accounting standard-setting bodies such as International Accounting Standards Board (IASB), as well as, concerned regulatory authorities in Bangladesh such as Bangladesh Securities and Exchange Commission (BSEC), Bangladesh Bank (BB) and the Institute of Chartered Accountants of Bangladesh (ICAB), should come forward to provide appropriate framework and detailed guidelines to ensure uniform CSR disclosure practices by national and international companies in all industries. The authorities mentioned above should pay special attention to provide a basic format for CSR reporting in the annual report. Banking companies also can introduce regular CSR reporting in the annual report through their consensus. BB should make it mandatory for all banks to put the 'Separate CSR Section' in annual report and guidelines for more quantitative as well as qualitative CSR disclosures.

\section{Limitation and Scope for Further Study}

Although numerous studies have been conducted around the world on CSR, it remains a debatable issue in many aspects. The above research is confined to the publicly traded commercial banks of Bangladesh and an attempt to investigate CSR disclosure in the annual report for a particular financial year. Similar further studies can be conducted with longitudinal data on other industries of development as well as developing countries context.

\section{Conclusion}

Acknowledging their responsibilities to society, the commercial banks of Bangladesh voluntarily practice CSR activities and disclose CSR information in their ways. This exploratory study has analyzed the contents of the annual report of a particular financial year of eighteen banking companies listed in DSE. It is found that their CSR disclosures are not detailed enough to justify their claims about broad CSR scope. The external users of annual reports do not get sufficient quantitative CSR information, particularly CSR expenditure for decision-making purposes. The concerned authorities, therefore, should come forward to make CSR practices and disclosures more accurate, transparent, and fair. Finally, it is hoped that the listed, as well as other banks of Bangladesh, will develop a uniform framework to communicate their respective CSR practices, so that the relevant stockholders, as well as stakeholders, will gain more confidence and trust in the ability of the banks to ethically undertake their economic activities as well as corporate social responsibility.

\section{References}

Adams C., Hill W., \& Roberts C. (1998). Corporate Social Reporting Practices in Western Europe: Legitimating Corporate Behavior. British Accounting Review, 30(1), 1-21.Belal, A. R. (2000). Environmental reporting in developing countries: empirical evidence from Bangladesh. Eco-Management and Auditing, 7(3), 114121. https://doi.org/10.1002/1099-0925(200009)7:3<114::aid-ema131>3.0.co;2-e

Belal, A. R. (2001). A study of corporate social disclosures in Bangladesh. Managerial Auditing Journal, 16(5), 274-289. https://doi.org/https://doi.org/10.1108/02686900110392922

Belal, A. R. (2008). Corporate Social Responsibility Reporting in Developing Countries: The Case of Bangladesh. https://doi.org/https://doi.org/10.4324/9781315574332

Belal, A. R., \& Cooper, S. (2011). The absence of corporate social responsibility reporting in Bangladesh. Critical Perspectives on Accounting, 22(7), 654-667. https://doi.org/10.1016/j.cpa.2010.06.020

Belal, A. R., \& Owen, D. L. (2007). The views of corporate managers on the current state of, and future prospects for, social reporting in Bangladesh: An engagement-based study. Accounting, Auditing and Accountability Journal, 20(3), 472-494. https://doi.org/10.1108/09513570710748599

Belal, A. R., \& Roberts, R. W. (2010). Stakeholders' Perceptions of Corporate Social Reporting in Bangladesh. Journal of Business Ethics, 97(2), 311-324. https://doi.org/10.1007/s10551-010-0511-4

Burritt, R. L., \& Schaltegger, S. (2010). Sustainability accounting and reporting: Fad or trend? In Accounting, 
Auditing \& Accountability Journal (Vol. 23). https://doi.org/10.1108/09513571011080144

Carroll, A. B. (1979). A three-dimensional conceptual model of corporate governance. Academy of Management Review, 4(4), 497-505. https://doi.org/10.5465/AMR.1979.4498296

Carroll, A. B. (1999). Corporate Social: Responsibility Evolution of a Definitional Construct. Business \& Society, 38(3), 268-295. https://doi.org/https://doi.org/10.1177/000765039903800303

Deegan, C., Rankin, M., \& Tobin, J. (2002). An examination of the corporate social and environmental disclosures of BHP from 1983-1997: A test of legitimacy theory. In Accounting, Auditing \& Accountability Journal (Vol. 15). https://doi.org/10.1108/09513570210435861

Fernández-Gago, R., Cabeza-García, L., \& Nieto, M. (2018). Independent directors' background and CSR disclosure. Corporate Social Responsibility and Environmental Management, 25(5), 991-1001. https://doi.org/10.1002/csr.1515

Friedman, M. (2007). The Social Responsibility of Business Is to Increase Its Profits. Corporate Ethics and Corporate Governance, 173-178. https://doi.org/10.1007/978-3-540-70818-6_14

Gray, R. (2006). Does sustainability reporting improve corporate behaviour?: Wrong question? Right time? Accounting and Business Research, 36(sup1), 65-88. https://doi.org/10.1080/00014788.2006.9730048

Gray, R., Kouhy, R., \& Lavers, S. (1995a). Corporate social and environmental reporting: a review of the literature and a longitudinal study of UK disclosure. Accounting, Auditing \& Accountability Journal, 8(2), 47-77. https://doi.org/https:// doi.org/10.1108/09513579510146996 Permanent

Gray, R., Kouhy, R., \& Lavers, S. (1995b). Methodological themes Constructing a research database of social and environmental reporting by UK companies. Accounting, Auditing \& Accountability Journa, 8(2), 78-101. https://doi.org/https://doi.org/10.1108/09513579510086812

Gray, R., Owen, D., \& Maunders, K. (1988). Corporate Social Reporting: Emerging Trends in Accountability and the Social Contract. Accounting, Auditing \& Accountability Journal, 1(1), 6-20. https://doi.org/https://doi.org/10.1108/EUM0000000004617

Hackston, D., \& Milne, M. J. (1996). Some determinants of social and environmental disclosures in New Zealand companies. Accounting, Auditing \& Accountability Journal, 9(1), 77-108.

Hamid, F. Z. A. (2004). Corporate social disclosure by banks and finance companies: Malaysian evidence. Corporate Ownership and Control, 1(4), 118-130. https://doi.org/10.22495/cocv1i4p10

Haque, M. Z., \& Azmat, F. (2015). Corporate social responsibility, economic globalization and developing countries: A case study of the ready made garments industry in Bangladesh. Sustainability Accounting, Management and Policy Journal, 6(2), 166-189. https://doi.org/10.1108/SAMPJ-04-2014-0028

Hossain, M. A., Islam, M. K. S., \& Andrew, J. (2006). Corporate Social and Environmental Disclosure in Developing Countries: Evidence from Bangladesh. Proceedings of the Asian Pacific Conference on International Accounting Issues, Hawaii, October 2006. Research, 1-22. https://doi.org/10.5267/j.msl.2012.10.037

Hossain, M. M., \& Alam, M. (2016). Corporate social reporting (CSR) and stakeholder accountability in Bangladesh. International Journal of Accounting \& Information Management, 24(4), 415-442. https://doi.org/10.1108/ijaim-05-2016-0064

Imam, S. (2000). Corporate social performance reporting in Bangladesh. Managerial Auditing Journal, 15(3), 133142. https://doi.org/https://doi.org/10.1108/02686900010319384

Islam, K. Z. (2012). Corporate Social Responsibility ( CSR ) and Issue to Corporate Financial Performance ( CFP ): An Empirical Evidence on Dhaka Stock Exchange ( DSE ) Listed Banking Companies in Bangladesh. European Journal Of Business and Management, ISSN 2222-1905 (Paper) ISSN 2222-2839 (Online), 4(11), 18-27.

Jones, M. T. (1996). Social responsibility and the green business firm. Industrial \& Environmental Crisis Quartely, 9(3), 327-345. https://doi.org/doi:10.1177/108602669600900303

Karim, R. Al, \& Kasim, A. (2018). Urgent Need for CSR in Bangladesh with an Emphasis on Environmental Urgent Need for CSR in Bangladesh with an Emphasis on Environmental Issues. Knowledge Management International Conference (KMICe), Miri Sarawak,2018, $25 \quad-27$ July 2018, Malaysia 
Http://Www.Kmice.Cms.Net.My/, (25-27 July). Retrieved from http://www.kmice.cms.net.my/

Khatun, M. M. (2014). Corporate Social Responsibility in Bangladesh: The Law and Practices. Journal of Law, 31, 2224-3259.

Kiliç, M., Kuzey, C., \& Uyar, A. (2015). The impact of ownership and board structure on corporate social responsibility (CSR) reporting in the Turkish banking industry. Corporate Governance (Bingley), 15(3), 357-374. https://doi.org/10.1108/CG-02-2014-0022

Kong, G. S. (1996). Social disclosure by Australian listed mineral mining companies: A stakeholder approach (Edith Cowan University). Retrieved from https://ro.ecu.edu.au/theses/971

Krippendorf, K. (2004). Content Analysis: An Introduction to Its Methodology. In SAGE Publications (Second). https://doi.org/10.1007/978-3-322-81888-1_2

Kuasirikun, N., \& Sherer, M. (2004). Corporate social accounting disclosure in Thailand. In Accounting, Auditing \& Accountability Journal (Vol. 17). https://doi.org/10.1108/09513570410554588

Luethge, D., \& Han, H. G. (2012). Assessing corporate social and financial performance in China. Social Responsibility Journal, 8(3), 389-403. https://doi.org/10.1108/17471111211247965

Mahbuba, S., \& Farzana, N. (2013). Corporate Social Responsibility and Profitability: A Case Study on Dutch Bangla Bank Ltd . International Journal of Business and Social Research, 3(4), 139-145.

Mohammad, N., \& Kamal, S. (2016). Social Impact and Sustainability of Corporate Social Responsibility in the Banking Sectors: Bangladesh Perspective. Asian Business Review, 6(1), 39. https://doi.org/10.18034/abr.v6i1.802

Momin, M. A., \& Parker, L. D. (2013). Motivations for corporate social responsibility reporting by MNC subsidiaries in an emerging country: The case of Bangladesh. British Accounting Review, 45(3), 215-228. https://doi.org/10.1016/j.bar.2013.06.007

Murthy, V. (2008). Corporate Social Disclosure Practices of Top Software Firms in India. Global Business Review, 9(2), 173-188. https://doi.org/10.1177/097215090800900201

O’Dwyer, B., Unerman, J., \& Bradley, J. (2005). Perceptions on the emergence and future development of corporate social disclosure in Ireland: Engaging the voices of non-governmental organisations. Accounting, Auditing and Accountability Journal, 18(1), 14-43. https://doi.org/10.1108/09513570510584647

Othman, R., \& Ameer, R. (2009). Corporate social and environmental reporting: Where are we heading a survey of the literature. International Journal of Disclosure and Governance, 6(4), 298-320. https://doi.org/10.1057/jdg.2009.7

Porag, R. sobhan. (2014). Corporate Social Responsibility in Bangladesh: Practice and perpetuity. https://doi.org/10.1007/978-3-319-01532-3

Puncheva-Michelotti, P., Hudson, S., \& Jin, G. (2018). Employer branding and CSR communication in online recruitment advertising. Business Horizons, 61(4), 643-651. https://doi.org/10.1016/j.bushor.2018.04.003

Quazi, A., Rahman, Z., \& Keating, B. (2007). A Developing Country Perspective of Corporate Social Responsibility: A Test Case of Bangladesh. Proceedings of the Australian and New Zealand Marketing Academy Conference, (2789-2795).

Rahim, M. M. (2013). Legal Regulation of CSR in Weak Economies: The Case of Bangladesh. https://doi.org/10.1007/978-3-642-40400-9_6

Rahman, A. (2015). Corporate Social Responsibility in Bangladesh Financial Sector. CSR Review, Bangladesh Bank, Dhaka, Bangladesh, 1-3.

Reinhardt, F. L., Stavins, R. N., \& Vietor, R. H. K. (2008). Corporate social responsibility through an economic lens. Review of Environmental Economics and Policy, 2(2), 219-239. https://doi.org/10.1093/reep/ren008

Reynolds, M., \& Yuthas, K. (2008). Moral discourse and corporate social responsibility reporting. Journal of Business Ethics, 78(1-2), 47-64. https://doi.org/10.1007/s10551-006-9316-X

Roberts, C. B. (1991). Environmental Disclosures: A Note on Reporting Practices in Mainland Europe Clare. Accounting, Auditing \& Accountability Journal, 4 4(3), 194-200. https://doi.org/https://doi.org/10.1108/09513579110005536 Downloaded

Sarker, A. A. (2000). Regulation of Islamic banking in Bangladesh: Role of Bangladesh bank. International Journal 
of Islamic Financial Services, 2(1). Retrieved from http://podelise.ru:81/tw_files2/urls_299/2/d-1844/7zdocs/28.pdf

Sobhani, F. A., Amran, A., \& Zainuddin, Y. (2009). Revisiting the practices of corporate social and environmental disclosure in Bangladesh. Corporate Social Responsibility and Environmental Management, 16(3), 167183. https://doi.org/10.1002/csr.193

Sobhani, F. A., Amran, A., \& Zainuddin, Y. (2012). Sustainability disclosure in annual reports and websites: A study of the banking industry in Bangladesh. Journal of Cleaner Production, 23(1), 75-85. https://doi.org/10.1016/j.jclepro.2011.09.023

Sufian, M. (2012). Corporate social responsibility disclosure in corporate communication . Global Journal of Management and Business Research, 12(14), 149-153.

Tsang, E. W. K. (1998). A longitudinal study of corporate social reporting in Singapore: The case of the banking, food and beverages and hotel industries. Accounting, Auditing \& Accountability Journal, 11(5), 624-635. https://doi.org/10.1108/09513579810239873

Ullah, M. S. (2013). Corporate Social Responsibility Practices in the Banking Sector in Bangladesh - An Assessment. Bank Parikrama, XXXVIII(3 \& 4), 129-152.

Vartiak, L. (2016). CSR Reporting of Companies on a Global Scale. Procedia Economics and Finance, 39(November 2015), 176-183. https://doi.org/10.1016/s2212-5671(16)30276-3

Vourvachis, P., Woodward, T., Woodward, D. G., \& Patten, D. M. (2016). CSR disclosure in response to major airline accidents: a legitimacy-based exploration. Sustainability Accounting, Management and Policy Journal, 7(1), 26-43. https://doi.org/http://dx.doi.org/10.1108/SAMPJ-12-2014-0080

Walden, W. D., \& Schwartz, B. N. (1997). Environmental disclosures and public policy pressure. Journal of Accounting and Public Policy, 16(2), 125-154. https://doi.org/10.1016/s0278-4254(96)00015-4

Williams, S. M., \& Ho Wern Pei, C.-A. (1999). Corporate social disclosures by listed companies on their web sites: an international comparison. The International Journal of Accounting, 34(3), 389-419. https://doi.org/10.1016/s0020-7063(99)00016-3

Wise, V., \& Ali, M. M. (2009). Corporate Governance and Corporate Social Responsibility in Bangladesh with special reference to Commercial Banks. In AIUB Business Economics Working Paper Series Working Paper No. AIUB-BUS-ECON-2009-05. Retrieved from http://orp.aiub.edu/abewps-2009

Zeghal, D., \& Ahmed, S. A. (1990). Comparison of Social Responsibility Information Disclosure Media Used by Canadian Firms. Accounting, Auditing \& Accountability Journal, 3(1). https://doi.org/https://doi.org/10.1108/09513579010136343 